\title{
Future Euroson Schools
}

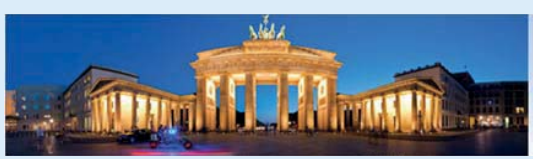

Interventional Ultrasound (INVUS)
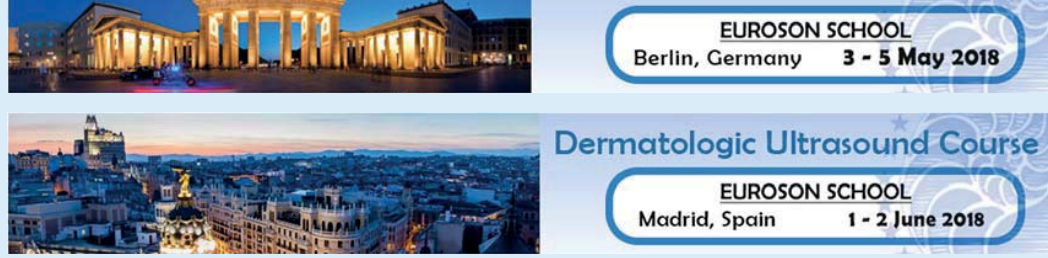

Dermatologic Ultrasound Course - Level 1

\begin{tabular}{lll}
\hline & EUROSON SCHOOL \\
Madrid, Spain 1 - 2 lune 2018
\end{tabular}

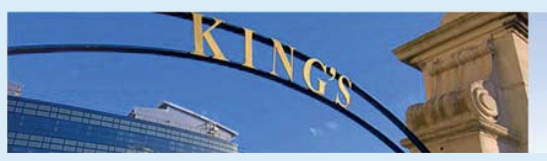

2nd International CEUS Course
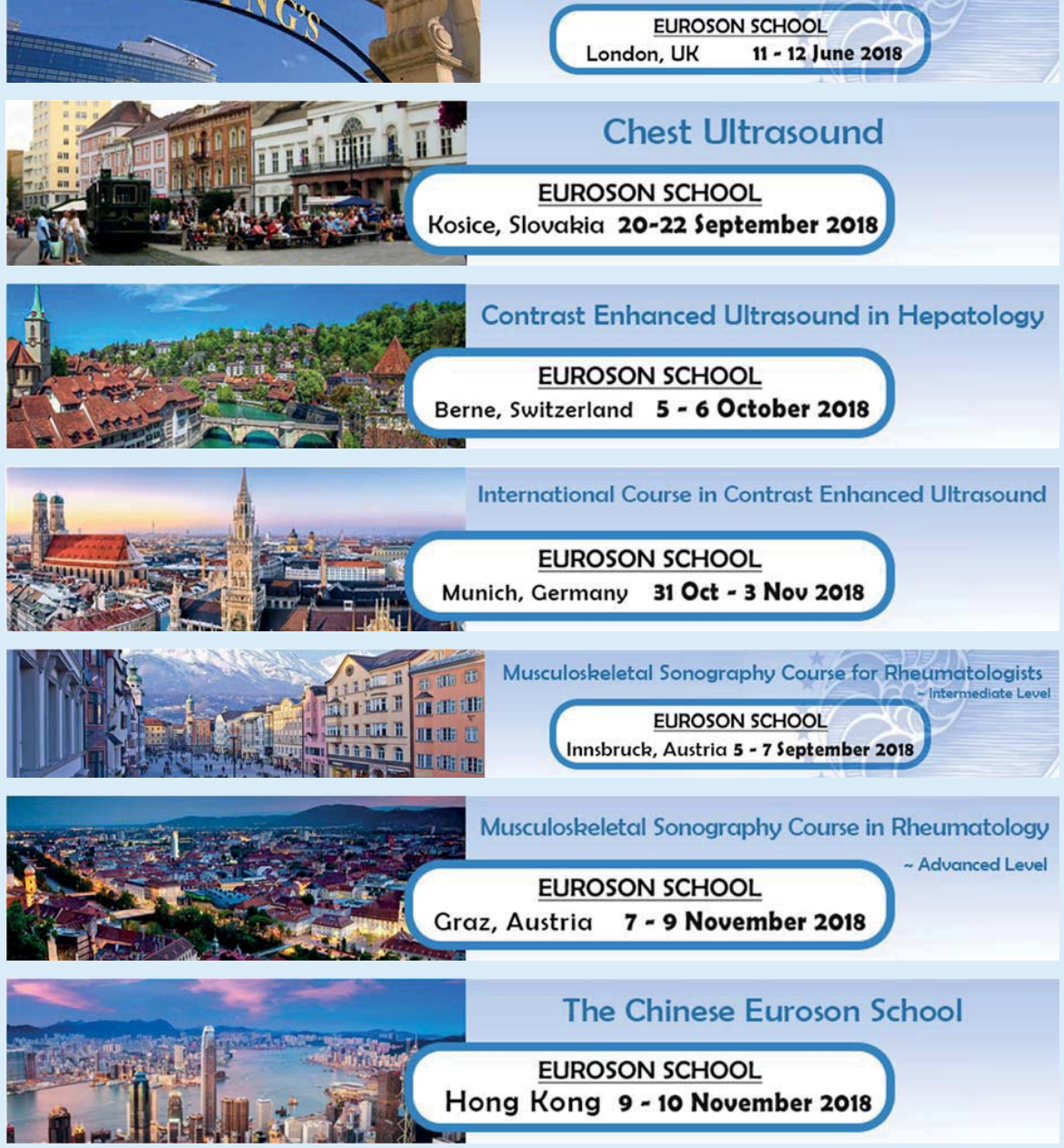